\title{
Permasalahan dalam Perencanaan Kebutuhan Sumber Daya Manusia Kesehatan di Kabupaten/Kota
}

\section{Problems in Planning of Human Resources Needs in the Districts/Cities in Indonesia}

\author{
Mimi Sumiarsih ${ }^{1}$, Iin Nurlinawati ${ }^{1}$ \\ 1) Pusat Penelitian dan Pengembangan Sumber Daya dan Pelayanan Kesehatan, Jalan Percetakan Negara No. 29 Jakarta \\ 10560, Indonesia \\ Korespondensi: mimi.smunadi@gmail.com
}

Submitted: 2 Oktober 2019, Revised: 18 Desember 2019, Accepted: 27 Desember 2019

https://doi.org/10.22435/jpppk.v3i3.2657

\begin{abstract}
Abstrak
Perencanaan kebutuhan sumber daya manusia kesehatan (SDMK) berdasarkan Permenkes No. 33 Tahun 2015 tentang Pedoman Penyusunan Rencana Kebutuhan SDMK, belum berjalan baik. Tujuan studi ini adalah menilai kegiatan perencanaan kebutuhan SDMK yang berbasis bukti di kabupaten/kota. Berdasarkan temuan yang diperoleh dalam studi ini diharapkan dapat menjadi masukan kebijakan dalam proses perencanaan kebutuhan SDMK. Metode kajian ini berupa studi literatur terhadap luaran Riset Ketenagaan di Bidang Kesehatan (Risnakes), hasil-hasil penelitian yang relevan, kepustakaan dan dokumen-dokumen terkait perencanaan SDMK, baik di tingkat nasional maupun daerah. Analisis data dari hasil studi literatur dibuat menggunakan tematik analisis. Pengembangan subtema yang ditetapkan dalam tematik analisis difokuskan untuk menggali permasalahan pada aspek input, proses, dan output dari pelaksanaan perencanaan kebutuhan SDMK pada kabupaten/kota di Indonesia. Hasil kajian memperlihatkan, permasalahan perencanaan kebutuhan SDMK pada input meliputi kebijakan pemerintah daerah dan manajemen ASN yang kompleks, kompetensi tenaga perencana yang rendah, dukungan pembiayaan yang minim, serta pemanfaatan data dan sistem informasi yang belum optimal. Permasalahan pada proses mencakup belum dipahami dan dilaksanakannya penyusunan kebutuhan SDMK secara tepat. Permasalahan pada output adalah kesenjangan SDMK terkait kecukupan jumlah dan jenis tenaga kesehatan di tingkat kabupaten/kota di Indonesia. Menyikapi hal tersebut, pemerintah daerah sebaiknya melakukan perencanaan kebutuhan SDMK berbasis bukti, sehingga dokumen perencanaan mampu memproyeksikan kebutuhan SDMK yang sesuai dengan situasi kesehatan terkini.
\end{abstract}

Kata kunci: SDM Kesehatan (SDMK); perencanaan SDMK, kebutuhan SDMK

\begin{abstract}
Planning for human health resources (HRK) based on Permenkes No. 33 of 2015 concerning Guidelines for the Preparation of HRH Needs Plans, has not gone well. The purpose of this study is to assess the evidencebased HR planning activities in the district / city. Based on the findings obtained in this study it is expected to be a policy input in the HRH needs planning process. The method of this study is in the form of a literature study of Workforce Research on Health Sector (Risnakes), relevance research results, literature and documents related to HRH planning both at national and regional levels. Data analysis of the results of the literature study was made using thematic analysis. The development of subthemes set in the thematic analysis is focused on exploring issues in the aspects of input, process, and output from the implementation of HRH needs planning in districts / cities in Indonesia. The results of the study show that HRK needs planning problems in the input include complex regional government and ASN management policies, low competency of planning personnel and lack of financial support and lack of optimal use of data and information systems. Problems in the process include not yet understood and implemented the preparation of HRH needs appropriately. The problem with
\end{abstract}


outputs is the gap in HRH related to the adequacy of the number and type of health workers at the municipal district level in Indonesia. In response to this, local governments should plan evidence-based HRH planning, so that planning documents are able to project HRH needs in accordance with the current health situation.

\section{Keywords: Human Resources for Health (HRH), HRH planning, HRH Need}

\section{Pendahuluan}

Perencanaan dalam konteks manajemen merupakan upaya institusi untuk menentukan tindakan yang tepat dengan menyediakan alternatif pilihan di masa mendatang melalui suatu proses sistematis. Menurut Green A (1999), perencanaan di bidang kesehatan dikategorikan ke dalam dua tipe. Tipe pertama adalah perencanaan aktivitas yang berkaitan dengan pengaturan jadwal dan kerangka kerja yang bisa dipantau untuk implementasi sebelum aktivitas dijalankan. Tipe kedua adalah perencanaan alokatif yang berhubungan dengan pengambilan keputusan terkait bagaimana sumber daya seharusnya dialokasikan agar efisien dan tepat sasaran. Tipe perencanaan alokatif ini yang umumnya dipakai di bidang kesehatan. Konsep ini diterjemahkan ke dalam kebijakan nasional perencanaan kebutuhan Sumber Daya Manusia (SDM) Kesehatan oleh pemerintah sebagai rancangan sistematis pemenuhan dan penempatan SDM Kesehatan (SDMK) berdasarkan jenis pelayanan dan fasilitas kesehatan yang dibutuhkan dengan komposisi jenis dan jumlah yang sesuai. ${ }^{1}$ Perencanaan SDMK yang tepat memungkinkan diketahuinya kapasitas kerja yang akurat agar didapatkan keseimbangan antara tenaga dengan beban kerja. $^{2}$

Peraturan Menteri Kesehatan RI Nomor 33 Tahun 2015 tentang Pedoman Penyusunan Perencanaan Kebutuhan SDMK menyatakan, SDMK adalah seseorang yang bekerja secara aktif di bidang kesehatan, baik yang memiliki pendidikan formal kesehatan maupun tidak, yang untuk jenis tertentu membutuhkan kewenangan dalam melakukan upaya kesehatan. Kebutuhan SDMK adalah jumlah SDMK menurut jenisnya yang dibutuhkan untuk melaksanakan sejumlah beban kerja yang ada. Sementara perencanaan kebutuhan SDMK adalah proses sistematis dalam upaya menetapkan jumlah, jenis, dan kualifikasi SDMK yang dibutuhkan, sesuai dengan kondisi suatu wilayah, dalam mencapai tujuan pembangunan kesehatan. Pada tingkat kabupaten/kota, proses tersebut dilihat menurut jenis, jumlah, dan kualifikasi yang dilakukan dalam lingkup kabupaten/kota. Secara berjenjang proses perencanaan kebutuhan SDMK tersebut dilakukan dari tingkat institusi ke tingkat kabupaten/kota, kemudian dilanjutkan ke tingkat provinsi, dan terakhir di tingkat nasional. ${ }^{3}$

Perencanaan kebutuhan SDMK menjadi salah satu fokus utama guna menjamin ketersediaan, pendistribusian, dan peningkatan kualitas SDMK. ${ }^{4}$ Sistem Kesehatan Nasional mendefinisikan SDMK sebagai tenaga kesehatan profesional, termasuk tenaga kesehatan strategis, tenaga kesehatan nonprofesi, serta tenaga pendukung/ penunjang kesehatan, yang terlibat dan bekerja serta mengabadikan dirinya dalam upaya dan manajemen kesehatan. ${ }^{5}$ Perencanaan kebutuhan SDMK di kabupaten/kota dimulai dengan melihat kebijakan terkait dengan perencanaan SDMK, pemenuhan kompetensi tenaga perencana serta adanya pembiayaan yang menunjang. Dalam proses perencanaan akan dilakukan upaya pemanfaatan data dan sistem informasi yang sesuai serta pelaksanaan metode dan perhitungan kebutuhan yang telah ditetapkan, sehingga akan dihasilkan output berupa perencanaan kebutuhan SDMK.

Permasalahan perencanaan kebutuhan SDMK akan berdampak pada inefisiensi dan hambatan produktivitas organisasi. Gambaran kasus yang terjadi pada perencanaan tenaga gizi memperlihatkan seringkali tenaga kesehatan yang ditetapkan tidak sesuai dengan kebutuhan nyata yang diajukan oleh fasilitas kesehatan. ${ }^{6}$ Beberapa penelitian memperlihatkan surplus tenaga kesehatan menyebabkan beban biaya menjadi besar, sedangkan defisit tenaga akan menciptakan beban kerja SDMK yang tinggi dan memengaruhi kualitas pelayanan. ${ }^{7,8}$ Adapun tujuan dari studi ini adalah menilai kegiatan perencanaan kebutuhan SDMK kesehatan yang berbasis bukti di kabupaten/kota. Berdasarkan temuan yang diperoleh diharapkan dapat menjadi masukan kebijakan dalam menyempurnakan proses perencanaan kebutuhan SDMK, sesuai dengan situasi spesifik yang menjadi tantangan 
implementasi di Indonesia.

\section{Metode}

Kajian ini merupakan studi literatur terhadap hasil-hasil penelitian yang relevan, kepustakaan dan dokumen-dokumen terkait perencanaan SDM Kesehatan (SDMK), baik di tingkat nasional maupun daerah. Hasil kajian dan penelitian meliputi hasil Risnakes tahun 2017, publikasi tentang implementasi perencanaan SDMK di institusi kesehatan, yakni rumah sakit (RS), puskesmas, dinas kesehatan, dan lainnya. Periode publikasi dibatasi mulai tahun 2005 hingga tahun 2019.

Kerangka pikir yang diadopsi adalah pendekatan sistem mengenai manajemen dan organisasi serta kerangka aksi SDMK (HRH action framework). Luasnya penggunaan konsep pendekatan sistem terkait dengan gagasan yang relatif praktis sehingga mudah diimplementasikan dalam berbagai permasalahan kebijakan, termasuk program kesehatan. Sementara itu HRH action framework dikembangkan untuk menjadi acuan bagi pengambil keputusan di level nasional dan daerah dalam menyusun strategi pengembangan tenaga kesehatan yang efektif dan berkesinambungan., ${ }^{910}$ Modifikasi dari teori HRH action framework terangkum dalam Gambar 1 dengan beberapa penyesuaian:

Analisis data dari hasil studi literatur dibuat menggunakan tematik analisis. Pengembangan subtema yang ditetapkan dalam tematik analisis difokuskan untuk menggali tantangan pada aspek input, proses, dan output dari pelaksanaan perencanaan SDMK pada kabupaten/kota di Indonesia.

\section{Hasil}

Hasil yang ditampilkan merupakan hasil Riset Ketenagaan Kesehatan (Risnakes) tahun $2017^{11}$ terkait Manajemen SDMK di puskesmas dan rumah sakit.

\section{Kondisi SDMK di Indonesia}

Hasil Risnakes memperlihatkan bahwa kondisi SDMK puskesmas di Indonesia dianggap masih kurang (82,5\%), hanya $12,7 \%$ yang menyatakan bahwa kondisi ketenagaan di puskesmasnya telah sesuai. Hal yang sama juga terjadi di rumah sakit di mana kondisi SDMK RS masih kurang sebesar 56,6\% sedangkan yang menyatakan telah sesuai hanya sebesar $38,9 \%$ (Tabel.1)

\section{Perencanaan kebutuhan}

Di tingkat nasional perencanaan SDMK menjadi salah satu masalah strategis yang diangkat dalam Sistem Kesehatan Nasional Tahun 2012; pelaksanaannya dinilai masih lemah dan belum didukung dengan tersedianya sistem informasi terkait SDMK yang memadai. ${ }^{12}$ Sesuai dengan Permenkes No. 33 Tahun 2015, rencana kebutuhan SDMK dibuat untuk melihat kebutuhan pada masingmasing level pemerintahan, baik dari segi jumlah, jenis, mutu, kualifikasi dan sebarannya. ${ }^{5}$ Hasil dari Risnakes menunjukkan bahwa tidak semua fasilitas pelayanan kesehatan menyusun kebutuhan SDMK, hanya $79,8 \%$ puskesmas dan $83,2 \%$ rumah sakit yang telah melakukannya. (Tabel 2)

Dalam Permenkes No. 33 Tahun 2015, perencanaan kebutuhan dilakukan melalui dua metode: (1) berdasarkan pendekatan institusi yang menggunakan Analisis Beban Kerja (ABK) dan standar ketenagaan minimal untuk keperluan perencanaan tahunan; dan (2) berdasarkan wilayah yang menggunakan data rasio tenaga kesehatan berbanding penduduk untuk kepentingan perencanaan jangka menengah. Selain itu juga ditekankan mekanisme penyusunan kebutuhan SDMK melalui perencanaan berjenjang mulai dari pemerintah daerah sampai ke pemerintah pusat. Hal ini juga ditegaskan kembali dalam Undang-Undang Nomor 36 Tahun 2014 tentang Tenaga Kesehatan Pasal 14 ayat 2, di mana perencanaannya diawali

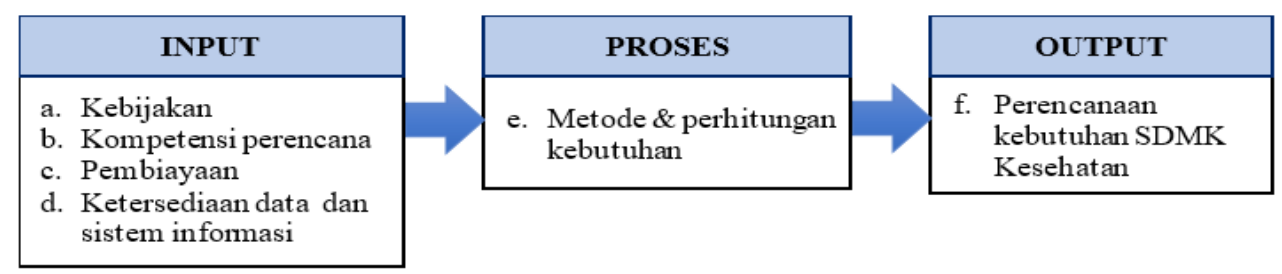

Gambar 1. Kombinasi Analisis Sistem dan HRH Action Framework ${ }^{9}$ 
Tabel 1. Kondisi SDMK Puskesmas dan Rumah Sakit, Risnakes 2017

\begin{tabular}{|c|c|c|c|c|c|c|c|}
\hline \multirow{2}{*}{ No } & \multirow{2}{*}{ Provinsi } & \multirow{2}{*}{$\begin{array}{c}\text { Jumlah } \\
\text { Puskesmas }\end{array}$} & \multicolumn{2}{|c|}{$\begin{array}{c}\text { Kondisi SDMK } \\
\text { puskesmas }\end{array}$} & \multirow{2}{*}{$\begin{array}{c}\text { Jumlah } \\
\text { Rumah } \\
\text { Sakit }\end{array}$} & \multicolumn{2}{|c|}{$\begin{array}{c}\text { Kondisi SDMK } \\
\text { Rumah Sakit }\end{array}$} \\
\hline & & & $\begin{array}{l}\text { Sesuai } \\
(\%)\end{array}$ & $\begin{array}{c}\text { Kurang } \\
(\%)\end{array}$ & & $\begin{array}{l}\text { Sesuai } \\
(\%)\end{array}$ & $\begin{array}{c}\text { Kurang } \\
(\%)\end{array}$ \\
\hline 1 & Aceh & 210 & 18,1 & 68,6 & 29 & 24,1 & 69,0 \\
\hline 2 & Sumatera Utara & 351 & 12,3 & 80,9 & 64 & 35,9 & 60,9 \\
\hline 3 & Sumatera Barat & 233 & 9,0 & 88,4 & 34 & 38,2 & 50,0 \\
\hline 4 & Riau & 164 & 14,6 & 78,7 & 31 & 45,2 & 41,9 \\
\hline 5 & Jambi & 142 & 12,0 & 78,2 & 19 & 57,9 & 42,1 \\
\hline 6 & Sumatera Selatan & 291 & 18,2 & 67,4 & 47 & 40,4 & 55,3 \\
\hline 7 & Bengkulu & 137 & 10,2 & 81,0 & 13 & 38,5 & 61,5 \\
\hline 8 & Lampung & 262 & 13,4 & 77,1 & 34 & 41,2 & 58,8 \\
\hline 9 & Kep, Bangka Belitung & 60 & 18,3 & 81,7 & 12 & 25,0 & 66,7 \\
\hline 10 & Kep, Riau & 64 & 12,5 & 84,4 & 17 & 17,6 & 70,6 \\
\hline 11 & DKI Jakarta & 151 & 22,0 & 77,3 & 112 & 46,4 & 48,2 \\
\hline 12 & Jawa Barat & 978 & 11,1 & 86,4 & 164 & 39,6 & 58,5 \\
\hline 13 & Jawa Tengah & 835 & 12,9 & 86,6 & 171 & 48,0 & 49,1 \\
\hline 14 & DI Yogyakarta & 121 & 10,7 & 89,3 & 43 & 53,5 & 44,2 \\
\hline 15 & Jawa Timur & 914 & 10,5 & 87,6 & 212 & 42,5 & 53,3 \\
\hline 16 & Banten & 202 & 9,4 & 87,6 & 49 & 51,0 & 49,0 \\
\hline 17 & Bali & 120 & 17,5 & 78,3 & 30 & 36,7 & 56,7 \\
\hline 18 & Nusa Tenggara Barat & 141 & 21,3 & 63,1 & 13 & 23,1 & 69,2 \\
\hline 19 & Nusa Tenggara Timur & 239 & 17,2 & 77,4 & 28 & 28,6 & 67,9 \\
\hline 20 & Kalimantan Barat & 196 & 13,8 & 83,2 & 26 & 30,8 & 65,4 \\
\hline 21 & Kalimantan Tengah & 156 & 10,9 & 82,7 & 15 & 6,7 & 93,3 \\
\hline 22 & Kalimantan Selatan & 201 & 9,5 & 88,6 & 21 & 47,6 & 42,9 \\
\hline 23 & Kalimantan Timur & 138 & 13,8 & 84,1 & 25 & 44,0 & 52,0 \\
\hline 24 & Kalimantan Utara & 36 & 16,7 & 80,6 & 4 & 25,0 & 75,0 \\
\hline 25 & Sulawesi Utara & 129 & 11,6 & 83,7 & 16 & 25,0 & 62,5 \\
\hline 26 & Sulawesi Tengah & 146 & 11,0 & 79,5 & 18 & 5,6 & 88,9 \\
\hline 27 & Sulawesi Selatan & 396 & 10,9 & 81,3 & 49 & 26,5 & 67,3 \\
\hline 28 & Sulawesi Tenggara & 183 & 11,5 & 81,4 & 13 & 15,4 & 84,6 \\
\hline 29 & Gorontalo & 86 & 11,6 & 79,1 & 8 & 25,0 & 75,0 \\
\hline 30 & Sulawesi Barat & 72 & 5,6 & 90,3 & 3 & 0,0 & 100,0 \\
\hline 31 & Maluku & 100 & 12,0 & 79,0 & 15 & 0,0 & 86,7 \\
\hline 32 & Maluku Utara & 62 & 8,1 & 83,9 & 3 & 0,0 & 66,7 \\
\hline 33 & Papua Barat & 84 & 13,1 & 82,1 & 9 & 33,3 & 66,7 \\
\hline \multirow[t]{2}{*}{34} & Papua & 139 & 15,1 & 82,0 & 15 & 20,0 & 60,0 \\
\hline & INDONESIA & 7.739 & 12,7 & 82,5 & 1.362 & 38,9 & 56,6 \\
\hline
\end{tabular}


Tabel 2. Penyusunan Perencanaan Kebutuhan SDMK di Puskesmas dan Rumah Sakit, Risnakes 2017

\begin{tabular}{|c|c|c|c|c|c|c|c|}
\hline \multirow{2}{*}{ No } & \multirow{2}{*}{ Provinsi } & \multirow{2}{*}{$\begin{array}{l}\text { Jumlah } \\
\text { Puskesmas }\end{array}$} & \multicolumn{2}{|c|}{$\begin{array}{c}\text { Menyusun } \\
\text { Kebutuhan SDMK }\end{array}$} & \multirow{2}{*}{$\begin{array}{c}\text { Jumlah } \\
\text { Rumah } \\
\text { Sakit }\end{array}$} & \multicolumn{2}{|c|}{$\begin{array}{c}\text { Menyusun } \\
\text { Kebutuhan SDMK }\end{array}$} \\
\hline & & & $\begin{array}{l}\text { Ya } \\
(\%)\end{array}$ & $\begin{array}{l}\text { Tidak } \\
(\%)\end{array}$ & & $\begin{array}{l}\text { Ya } \\
(\%)\end{array}$ & $\begin{array}{c}\text { Tidak } \\
(\%)\end{array}$ \\
\hline 1 & Aceh & 340 & 61,8 & 38,2 & 62 & 75,8 & 24,2 \\
\hline 2 & Sumatera Utara & 571 & 61,5 & 38,5 & 158 & 64,6 & 35,4 \\
\hline 3 & Sumatera Barat & 264 & 88,3 & 11,7 & 54 & 88,9 & 11,1 \\
\hline 4 & Riau & 212 & 77,4 & 22,6 & 66 & 74,2 & 25,8 \\
\hline 5 & Jambi & 176 & 80,7 & 19,3 & 31 & 90,3 & 9,7 \\
\hline 6 & Sumatera Selatan & 322 & 90,4 & 9,6 & 61 & 90,2 & 9,8 \\
\hline 7 & Bengkulu & 179 & 76,5 & 23,5 & 21 & 76,2 & 23,8 \\
\hline 8 & Lampung & 291 & 90,0 & 10,0 & 60 & 83,3 & 16,7 \\
\hline 9 & Kep, Bangka Belitung & 62 & 96,8 & 3,2 & 17 & 100,0 & 0,0 \\
\hline 10 & Kep, Riau & 72 & 88,9 & 11,1 & 23 & 78,3 & 21,7 \\
\hline 11 & DKI Jakarta & 314 & 47,8 & 52,2 & 167 & 87,4 & 12,6 \\
\hline 12 & Jawa Barat & 1050 & 93,1 & 6,9 & 290 & 79,0 & 21,0 \\
\hline 13 & Jawa Tengah & 875 & 95,4 & 4,6 & 270 & 87,8 & 12,2 \\
\hline 14 & DI Yogyakarta & 121 & 100,0 & 0 & 70 & 90,0 & 10,0 \\
\hline 15 & Jawa Timur & 960 & 95,2 & 4,8 & 327 & 87,8 & 12,2 \\
\hline 16 & Banten & 233 & 86,7 & 13,3 & 87 & 88,5 & 11,5 \\
\hline 17 & Bali & 120 & 100,0 &, 0 & 51 & 90,2 & 9,8 \\
\hline 18 & Nusa Tenggara Barat & 158 & 89,2 & 10,8 & 28 & 82,1 & 17,9 \\
\hline 19 & Nusa Tenggara Timur & 371 & 64,4 & 35,6 & 45 & 88,9 & 11,1 \\
\hline 20 & Kalimantan Barat & 238 & 82,4 & 17,6 & 43 & 79,1 & 20,9 \\
\hline 21 & Kalimantan Tengah & 195 & 80,0 & 20,0 & 20 & 85,0 & 15,0 \\
\hline 22 & Kalimantan Selatan & 230 & 87,4 & 12,6 & 34 & 88,2 & 11,8 \\
\hline 23 & Kalimantan Timur & 174 & 79,3 & 20,7 & 44 & 84,1 & 15,9 \\
\hline 24 & Kalimantan Utara & 46 & 78,3 & 21,7 & 7 & 71,4 & 28,6 \\
\hline 25 & Sulawesi Utara & 186 & 69,4 & 30,6 & 38 & 94,7 & 5,3 \\
\hline 26 & Sulawesi Tengah & 189 & 77,2 & 22,8 & 26 & 84,6 & 15,4 \\
\hline 27 & Sulawesi Selatan & 448 & 88,4 & 11,6 & 83 & 80,7 & 19,3 \\
\hline 28 & Sulawesi Tenggara & 268 & 68,3 & 31,7 & 27 & 81,5 & 18,5 \\
\hline 29 & Gorontalo & 93 & 92,5 & 7,5 & 13 & 69,2 & 30,8 \\
\hline 30 & Sulawesi Barat & 94 & 76,6 & 23,4 & 9 & 77,8 & 22,2 \\
\hline 31 & Maluku & 198 & 50,5 & 49,5 & 26 & 76,9 & 23,1 \\
\hline 32 & Maluku Utara & 127 & 48,8 & 51,2 & 17 & 70,6 & 29,4 \\
\hline 33 & Papua Barat & 150 & 56,0 & 44,0 & 16 & 81,3 & 18,8 \\
\hline \multirow[t]{2}{*}{34} & Papua & 372 & 37,4 & 62,6 & 33 & 75,8 & 24,2 \\
\hline & INDONESIA & 9.699 & 79,8 & 20,2 & 2.324 & 83,2 & 16,8 \\
\hline
\end{tabular}


dari instansi kesehatan, kemudian direkapitulasi oleh kabupaten/kota untuk disampaikan kepada pemerintah pusat melalui provinsi. ${ }^{13}$ Pada pelaksanaannya di lapangan, mekanisme pengusulan secara bottom-up nyatanya belum disertai dengan pemahaman merata mengenai keseluruhan tahapan perencanaan SDMK hingga level pengambil kebijakan teknis., ${ }^{2,714}$

\section{Pembahasan}

Dalam setiap tahapan perencanaan dijumpai kendala dan kesulitan pelaksanaan sebagai tantangan dari implementasi perencanaan SDMK yang meliputi input, proses, dan output.

\section{a. Kebijakan}

Kebijakan terkait formasi SDM aparatur diatur secara terpusat, di mana Kementerian Pendayagunaan Aparatur Negara dan Badan Kepegawaian Negara, dalam proses penetapan formasi, berkoordinasi dengan Badan Kepegawaian Daerah (BKD). Oleh karena itu BKD memiliki kekuatan lebih besar dibandingkan institusi lainnya di daerah dalam menentukan alokasi kuota yang diberikan oleh Pusat. Perbedaan kewenangan dalam pengusulan dan persetujuan formasi tenaga kesehatan menjadi faktor yang menyebabkan adanya kesenjangan antara usulan yang disampaikan dan formasi yang akhirnya ditetapkan dalam hal jumlah, jenis, distribusi, dan kualifikasi. Gambaran kasus yang terjadi, hasil yang ditetapkan seringkali tidak sesuai dengan kebutuhan riil yang diajukan oleh fasilitas kesehatan. ${ }^{6}$ Selain itu, adanya sejumlah kebijakan nasional dalam hal pemenuhan ketenagaan menjadi tantangan tersendiri. Salah satu kebijakan yang menjadi tantangan yaitu kebijakan moratorium pengangkatan CPNS, padahal kebutuhan akan tenaga kesehatan menjadi isu yang mendesak. Proyeksi peningkatan kebutuhan SDMK trennya terus meningkat seiring dengan lahirnya programprogram penguatan upaya kesehatan, salah satunya diperlihatkan dalam sebuah studi di Sumatera Utara di mana perkiraan kebutuhan tenaga kesehatan pada tahun 2015 menjadi dua kali lipat dibandingkan kebutuhan pada $2010 .{ }^{15}$

Pemberlakuan otonomi daerah tahun 1999 menyebabkan lompatan perubahan yang signifikan dalam tata kelola pemerintahan di Indonesia. Penerapan asas dekonsentrasi dan desentralisasi dipersepsikan daerah sebagai independensi dalam mengelola wilayah administratifnya. Sesuai dengan peraturan perundang-undangan mengenai pemerintah daerah, yakni UU Nomor 2 tahun 2014, penanganan bidang kesehatan menjadi salah satu urusan wajib yang kewenangannya sudah diserahkan kepada pemerintah daerah provinsi. Transfer kewenangan yang diserahkan meliputi sumber pendanaan, pengalihan sarana dan prasarana, serta aspek kepegawaian. Dengan demikian, pengelolaan termasuk perencanaan SDMK saat ini praktis menjadi kewajiban dan tanggung jawab pemerintah provinsi. Sementara pembangunan kesehatan dengan sejumlah sasaran strategisnya memiliki tantangan kompleks yang tidak memungkinkan untuk diatasi sendirian oleh Kementerian Kesehatan tanpa sokongan di tingkat daerah. Pada akhirnya tarik-menarik kepentingan antara pemerintah pusat dan daerah menjadi tak terelakkan. ${ }^{1}$

Acuan jumlah tenaga kesehatan di fasilitas pelayanan kesehatan tertuang dalam Keputusan Menteri Pendayagunaan Aparatur Negara No 75 tahun 2004 tentang pedoman perhitungan kebutuhan pegawai berdasarkan beban kerja dalam rangka penyusunan formasi PNS. Kepmenkes tersebut memastikan rencana kebutuhan SDMK yang disusun telah sesuai dengan kebutuhan nyata organisasi, baik dari segi jumlah, mutu, kualifikasi, maupun sebarannya. ${ }^{16}$ Namun, lahirnya agenda reformasi birokrasi berimplikasi terhadap perombakan yang relatif masif terhadap manajemen SDM aparatur nasional. Upaya harmonisasi antar kementerian dan lembaga terkait dalam menjembatani sejumlah perbedaan kebijakan menjadi esensial termasuk di dalamnya mengenai sistem, metode, dan unsurunsur dalam perhitungan kebutuhan SDM. Oleh karena perencanaan SDMK tidak dapat dipisahkan dari kerangka besar manajemen SDM aparatur nasional, maka metode penyusunan kebutuhan perlu disempurnakan untuk mengakomodasi penyesuaian kebijakan yang disepakati melalui Permenkes No. 33 Tahun 2015. ${ }^{5}$

\section{b. Kompetensi Tenaga Perencana}

Isu penting yang turut menjadi ancaman dalam perencanaan SDMK adalah rendahnya kemampuan tenaga perencana, baik di tingkat pusat maupun daerah. Sebuah studi di Kabupaten 
Muaro Jambi mengungkapkan, tidak ada tenaga perencana khusus yang memiliki keahlian dalam penyusunan rencana kebutuhan SDM di lingkungan puskesmas karena ketiadaan pendidikan dan pelatihan yang sesuai. ${ }^{17}$ Dalam tataran aplikatif di lapangan, tahapan inventarisasi yang dilaksanakan dalam perencanaan kebutuhan oleh pemerintah Kota Pekanbaru, sebagai contoh, hanya sebatas melakukan pendataan jumlah tenaga. Akibatnya, asupan pemetaan kebutuhan hanya berdasarkan pertimbangan jumlah dan kualifikasi. Begitupun dalam hal metode yang digunakan belum baku dan tidak mengikuti kaidah yang jelas. ${ }^{18}$ Hasil penelitian lainnya di RS mengungkapkan fakta bahwa perencanaan kebutuhan didasari persepsi kebutuhan dari setiap kepala instalasi, bukan sebagai proses bisnis yang sudah terukur dan terproyeksi mengikuti perubahan visi dan tuntutan organisasi.

Tenaga perencana SDMK idealnya mampu menginventarisasi data dari berbagai instansi, kemudian menganalisisnya sesuai opsi metode perencanaan agar dihasilkan dokumen perencanaan kebutuhan SDMK yang dapat dipertanggungjawabkan. Analisis tersebut meliputi kesenjangan antara ketersediaan dan kebutuhan, proyeksi kebutuhan dalam jangka waktu tertentu, serta peta distribusi SDMK berbasiskan wilayah. Komitmen pemerintah daerah juga dinilai belum optimal dalam hal fasilitasi peningkatan kapasitas tenaga perencana tersebut. Hal ini dalam perspektif lebih luas, akan menghambat jalannya organisasi karena kebutuhan jenis dan jumlah SDM kesehatan yang dibutuhkan tidak bisa dihitung dengan akurat. ${ }^{19}$ Hapsara dalam Guspianto (2012) mengungkapkan, isu krusial dalam perencanaan pembangunan dan pengembangan SDMK adalah kapasitas perencana kebijakan dan program SDMK yang masih lemah. ${ }^{20}$

\section{c. Pembiayaan}

Salah satu permasalahan yang menjadi kendala dalam perencanaan SDMK adalah kurangnya komitmen pemerintah daerah dalam memberikan dukungan anggaran dalam peningkatan kapasitas tenaga perencana maupun tindak lanjut terhadap dokumen perencanaan kebutuhan SDMK. Perkiraan kebutuhan SDMK di provinsi Sumatera Utara pada tahun 2015 bila dibandingkan dengan tahun 2010, rata-rata naik sebanyak dua kali lipatnya. Kenaikan ini merupakan konsekuensi dari kebijakan daerah dalam upaya pemerataan tenaga kesehatan. Hal ini menjadi tantangan tersendiri dikarenakan keterbatasan anggaran untuk melakukan rekruitmen dan pengadaan tenaga kesehatan. ${ }^{15}$ Ketiadaan pembiayaan yang memadai menyebabkan pelaksanaan tahapan-tahapan dalam penyusunan rencana kebutuhan SDMK tidak berjalan secara optimal dan komprehensif, terutama dalam hal proses pengumpulan data. ${ }^{21}$ Menurut Hapsara dalam Guspianto (2012), ketidak tersediaan anggaran mendeskripsikan rendahnya atensi dalam bentuk dukungan sumber daya bagi pengembangan SDMK, terutama di tingkat daerah..$^{20}$

\section{d. Pemanfaatan Data dan Sistem Informasi}

Kendala proses perencanaan yang memakan waktu, kurangnya sosialisasi, dan keterbatasan kewenangan yang dimiliki oleh dinas kesehatan provinsi dalam rangkaian proses perekrutan tenaga di daerah menyebabkan minimnya minat untuk melakukan perencanaan yang sesuai kaidah. ${ }^{6}$ Sayangnya, informasi ketenagaan di Indonesia belum terakomodasi dalam sebuah sistem informasi kesehatan yang terintegrasi untuk menunjang efisiensi pekerjaan perencana. Sebagai contoh yang terjadi di lingkungan Dinas Kesehatan Muaro Jambi, di mana informasi kepegawaian masih dilaporkan secara manual, sehingga kejadian sejumlah mobilitas tenaga (pindah atau mutasi) luput dari pencatatan. ${ }^{20}$ Hal ini sesuai dengan yang dikemukakan Ilyas (2013), di mana penyusunan perencanaan kebutuhan SDMK di daerah seringkali tidak lengkap, tidak adekuat dan akurat, tidak terolah secara sistematis dan kurang terdokumentasi dengan baik, sehingga dalam proses penyusunannya menemui kesulitan dalam mencari formula yang tepat. ${ }^{17}$ Permasalahan lainnya yang muncul adalah komitmen untuk memanfaatkan sistem informasi yang ada sebagai bahan perencanaan SDMK dan pengambilan keputusan. Implementasi di lapangan, data yang terekam dalam sistem informasi yang dibangun masih belum didayagunakan secara optimal oleh seluruh pemangku kebijakan perencanaan SDMK. Umumnya pemanfaatan baru dilakukan oleh divisi atau bidang yang membangun sistem informasi tersebut. ${ }^{22}$ 
Salah satu implikasi negatif dari kebijakan desentralisasi adalah putusnya sistem informasi dari level daerah ke pusat, termasuk dalam hal informasi tenaga kesehatan. Konsekuensi dari prinsip otonomi tersebut, daerah merasa tidak lagi berkewajiban untuk melaporkan data tenaga kesehatan ke level pemerintahan pusat. Akibatnya, asupan data bagi perencanaan tenaga kesehatan nasional tidak didukung kecukupan data yang akurat. ${ }^{1}$ Dalam situasi lemahnya kualitas perencanaan kebutuhan SDM kesehatan akibat ketiadaan informasi pendukung, alih-alih terus mencari model perencanaan yang tepat, lebih penting mengedepankan komitmen untuk mengalokasikan investasi sumber daya pada perbaikan kualitas data dan sistem informasi. ${ }^{23} \mathrm{Hal}$ ini secara otomatis akan mempermudah pemerintah dalam mengidentifikasi kebutuhan SDMK berdasarkan kebutuhan jenis pelayanan, kompetensi tenaga kesehatan dan situasi lingkungan yang spesifik.

Dalam konteks budaya kerja saat ini, teknologi yang mendukung pelaksana kerja diakui sebagai salah satu dari tiga pilar utama dalam mencapai kinerja SDM yang optimal. ${ }^{2}$ Perencanaan SDMK tentunya tidak terlepas dari dukungan data dan informasi SDMK. Dalam proses penyusunannya diperlukan sumber informasi beragam dari dalam maupun luar sektor kesehatan sesuai metode perencanaan kebutuhan yang akan diadopsi. Data-data yang dinilai penting di antaranya data institusi dan fasilitas kesehatan, data ketersediaan SDM menurut jumlah maupun jenis, data jumlah penduduk, gambaran demografi dan geografi, dan data epidemiologis, seperti kasus penyakit endemik. ${ }^{20}$

\section{e. Pelaksanaan Metode Perhitungan Kebutuhan}

Proses perencanaan SDMK yang berjalan pada institusi kesehatan di Indonesia secara umum telah mempergunakaan metode spesifik, seperti analisis beban kerja dengan memperhatikan standarstandar yang telah ditetapkan pemerintah. Sebagai contoh, pada perencanaan di RS dituntut untuk memenuhi persyaratan akreditasi RS dalam hal penentuan jumlah dan spesifikasi tenaga. Akan tetapi dalam hal keseluruhan pelaksanaan, ditemukan masih ada prinsip-prinsip yang belum diadopsi secara tepat. Titik kritis proses yang masih lemah salah satunya adalah pelaksanaan analisis jabatan (job analysis), di mana seringkali bergantung pada kebijakan organisasi semisal kecenderungan prioritas pada tenaga medis tertentu saja. Saat ini perhitungan kebutuhan dengan metode WISN dianggap sebagai standar emas, yang diyakini dapat menggambarkan beban kerja secara akurat. Ratio WISN dapat menjadi ukuran pengganti (proxy) bagi tekanan kerja yang dihadapi SDM dalam aktivitas kerja sehari-hari. Pada situasi rasio WISN yang lebih kecil dari satu, menggambarkan adanya inefisiensi pemborosan tenaga yang berimplikasi kepada kelebihan beban kompensasi kepada pegawai. ${ }^{24}$ Hasil perhitungan kebutuhan SDM dengan berbasis metode dan bukti ilmiah diharapkan dapat memproyeksikan ketersediaan SDMK di masa mendatang secara akurat. Proyeksi dilihat berdasarkan jumlah ketersediaan dan asal tenaga kesehatan saat ini serta aliran masuk dan keluarnya. Hal ini berguna untuk memproyeksikan jumlah SDMK yang dibutuhkan di masa depan, sehingga masyarakat dapat terus mengakses pelayanan kesehatan dan mendapatkan manfaatnya. ${ }^{25}$

Isu kebijakan, baik kesehatan maupun nonkesehatan, dinilai turut berkontribusi terhadap perkembangan kebutuhan SDMK. Contoh muatan kebijakan dalam bidang kesehatan yang turut memengaruhi antara lain penetapan prioritas dan parameter baru terkait kesehatan. Sementara itu, isu pendidikan, ketenagaan, dan pengembangan wilayah diyakini membawa pengaruh tidak langsung dari sektor nonkesehatan. Hal tersebut dibuktikan pada penelitian mengenai ketersediaan tenaga di FKTP pada 4 provinsi di pulau Jawa, di mana diakui terdapat perubahan perencanaan SDM antara sebelum dan sesudah pemberlakuan Jaminan Kesehatan Nasional. ${ }^{26}$

\section{f. Kebutuhan SDM Kesehatan}

Situasi pada level institusi, yang menjadi isu utama kesenjangan adalah terdapat perbedaan cakupan tenaga dalam hal kecukupan jumlah, retensi, keahlian, dan kepuasan kerja antara fasilitas pelayanan kesehatan favorit dengan nonfavorit. Selain itu, isu gender nyatanya juga memiliki kaitan dengan situasi SDMK, di antaranya berupa 
kesempatan perempuan dalam mengakses pelatihan profesi dan posisi manajerial. Hal tersebut diyakini berimplikasi terhadap pengambilan keputusan di bidang SDMK yang kurang menangkap kebutuhan penanganan masalah dan model utilisasi spesifik bagi perempuan. Padahal, budaya pada sebagian masyarakat memperlihatkan adanya kecenderungan kaum perempuan lebih memilih opsi ditangani oleh bukan tenaga kesehatan (seperti paraji dll) ketika tidak tersedia tenaga kesehatan perempuan, terutama terkait pelayanan reproduksi dan anak. ${ }^{27}$

Dokumen perencanaan seharusnya juga memuat gambaran kesenjangan jumlah kebutuhan berdasarkan hasil analisis/perhitungan dengan ketersediaan tenaga menurut jumlah, jenis kompetensi, dan jabatan yang diduduki. Apabila dideteksi adanya ketidaksesuaian, maka institusi perlu mengambil tindakan korektif. Dalam situasi adanya ketidaksesuaian jumlah dan kompetensi dapat dilakukan kebijakan redistribusi, bahkan pengurangan tenaga, jika dimungkinkan. Oleh karena itu proses penetapan hasil perencanaan SDMK melibatkan beban psikologis tersendiri terkait potensi implikasi yang muncul. Moral hazard yang sayangnya seringkali dipraktikkan adalah dilakukan sejumlah penyesuaian agar hasil identifikasi dan proyeksi kebutuhan relatif sesuai dengan kondisi ketenagaan saat ini. ${ }^{6}$

Permasalahan yang muncul dalam pemanfaatan hasil perencanaan SDMK adalah lemahnya tindak lanjut terhadap dokumen perencanaan yang dihasilkan. Hal ini terjadi di Kota Depok, di mana pihak Dinas Kesehatan mengakui tidak melakukan diseminasi terhadap pihakpihak di luar instansinya, meskipun diakui sudah memanfaatkannya untuk dasar usulan formasi. Praktik ini tidak sesuai dengan amanah Permenkes 33 tahun 2015 yang mengatur adanya kegiatan tindak lanjut untuk menghimpun masukan lintas sektor. ${ }^{22}$ Perencanaan kebutuhan yang telah dilakukan perlu untuk ditinjau secara berkala sebagai tahap konfirmasi kebijakan. Jika semisal keputusan yang dipilih kurang tepat, maka perlu segera dilakukan perubahan kebijakan atau diantisipasi melalui penentuan rencana alternatif. Apabila aktivitas ini diimplementasikan, maka potensi ketidaksesuaian perencananaan dengan kebutuhan riil dapat diminimalisasi. ${ }^{18}$

\section{Kesimpulan}

Permasalahan pada perencanaan SDM Kesehatan (SDMK) masih ditemukan pada aspek input dan proses sehingga menghasilkan output kesenjangan SDM Kesehatan di berbagai level pemerintahan di Indonesia. Permasalahan utama meliputi kebijakan pemerintah daerah dan manajemen ASN yang kompleks, kompetensi tenaga perencana yang rendah, dan dukungan pembiayaan yang minim. Permasalahan proses mencakup belum optimalnya pemanfaatan data dan sistem informasi serta belum dipahami dan dilaksanakannya penyusunan kebutuhan SDMK secara tepat. Sementara itu, permasalahan output adalah kesenjangan SDMK terkait kecukupan jumlah dan jenis tenaga kesehatan.

\section{Saran}

Pemerintah daerah sebaiknya melakukan perencanaan SDM Kesehatan (SDMK) berbasis data sehingga dokumen perencanaan mampu memproyeksikan secara akurat perhitungan kebutuhan yang sesuai dengan situasi kesehatan terkini. Mengingat permasalahan perencanaan kebutuhan SDMK yang kompleks dan multidisiplin, maka dibutuhkan upaya serius dalam rangka harmonisasi regulasi dan penguatan koordinasi lintas sektor dari seluruh pemangku kepentingan, termasuk swasta dan masyarakat, baik di tingkat pusat maupun daerah. Dokumen perencanaan tersebut seharusnya dapat menjadi acuan pengelolaan ketenagaan tidak hanya terkait kebijakan perekrutan, namun termasuk juga di dalamnya rotasi dan promosi pegawai serta pendayagunaan tenaga, di mana salah satunya memperkuat opsi redistribusi sebagai langkah pemenuhan kebutuhan. Selain itu perlu penguatan sosialisasi dan implementasi pedoman perencanaan SDMK melalui penerapan mekanisme reward and punishment.

\section{Daftar Rujukan}

1. Kurniati A dan E. Kajian SDM Kesehatan di Indonesia. Jakarta Salemba Med 166 hlm. 2012.

2. Hendrayanti E. Analisis Beban Kerja Sebagai Dasar Perencanaan Kebutuhan SDM. J Univ Islam 45 Bekasi Paradigma 2008; 19(01). Tersedia pada: http//www.ejournalunisma.net/ojs/index.php/paradigma/article/ 
viewFile/111/106. 2008;

3. Kementerian Kesehatan. Peraturan Menteri Kesehatan No. 33 Tahun 2015 tentang Pedoman Penyusunan Rencana Kebutuhan Sumber Daya Manusia Kesehatan.2015.

4. AIPHSS. Mengembangkan Kapasitas Sumber Daya Manusia Kesehatan untuk Mendukung Tercapainya Jaminan Kesehatan Nasional dan TujuanPembangunanKesehatan.2016a.Tersedia pada:http://aiphss.org/id/national-workshopon-health -workforce-development-2/.

5. AIPHSS. Permenkes RI No 33 Tahun 2015: Kunci Harmonisasi dan Sinkronisasi antar Bidang dan antar Level Pemerintahan dalam Penyusunan Rencana Kebutuhan SDM Kesehatan.2015. Tersedia pada: http// aiphss.org/id/id-permenkes-ri-no-33-tahun2015-kunci-harmonisasi-dan-sinkronisasiantar-bidang-dan-antar-level-pemerintahandalam-penyusunan-rencana-kebutuhan-sdmkesehatan/.

6. Riyadi, D.M.S D. Perencanaan Tenaga Kesehatan. Laporan Kajian, Direktorat Kesehatan dan Gizi Masyarakat. Jakarta Badan Perenc Pembang Nasional. 2016.

7. Beswick S, Hill PD AM. Comparison of Nurse Workload Approaches. J Ners Manag 2010 Jul;18(5)592-8. https://doi.org/10.1111/j.13652834.2010.01124.x

8. Annisa Susanto N, Mansur M, Djauhari T. Analisis Kebutuhan Tenaga di Instalasi Farmasi RS Universitas Muhammadiyah Malang Tahun 2016. J Medicoeticolegal dan Manaj Rumah Sakit. 2017;6(2):82-90.

9. Hasanbasri M. Pendekatan Sistem dalam Perencanaan Program Daerah. J Manaj Pelayanan Kesehat. 2007;10(02):56-63.

10. Dal Poz MR, Dreesch N, Fletcher S, Gedik G, Gupta N, Hornby P, et al. Models and tools for health workforce planning and projections. Switzerland: World Health Organization, 2010.19p (Human resources for Health observer;3).

11. Kementerian Kesehatan, Badan Litbangkes. Laporan Riset Ketenagaan Kesehatan tahun 2017. Jakarta, 2017.

12. Republik Indonesia. Peraturan Presiden No. 72 Tahun 2012 tentang Sistem Kesehatan
Nasional.2012

13. AIPHSS. Pengayaan Model Sistem Informasi SDM Kesehatan. Tersedia pada: http://aiphss. org/id/id-pengayaan-model-sistem-informasisdm-kesehatan/. 2016;

14. Rakhmawati F, Rustiyanto E. Analisis Kebutuhan Petugas Rekam Medis Berdasarkan Beban Kerja di Instalasi Rekam Medis RS Aisyiah Muntilan. J Kesehat Vokasional. 2016;1(1):1-8. https:// doi.org/10.22146/jkesvo.27446

15. Santosa H. Kebutuhan dan Perencanaan Tenaga Kesehatan di Provinsi Sumatera Utara. J Kebijak Kesehat Indones Yogyakarta.2015;4(01):37-42 https://doi.org/10.22146/jkki.v4i1.36090.

16. Kemenpan. Pedoman Perhitungan Kebutuhan Pegawai Berdasarkan Beban Kerja Dalam Rangka Penyusunan Formasi Pegawai Negeri Sipil. Keputusan Nomor KEP/75/MPAN/7/2004 Jakarta Kemenpan RI. 2004.

17. Ilyas Yaslis. Perencanaan SDM Rumah Sakit: Teori, Metoda dan Formulasi. Depok FKM UI. 2013.

18. Marlinda P. Analisis Perencanaan Kebutuhan Tenaga Dokter oleh Dinas Kesehatan Kota Pekanbaru. J Niara.2017:9(2):71-83. https://doi. org/10.31849/nia.v9i2.2100

19. Dinkes Provinsi Bali. ABK membantu Perencanaan Kebutuhan SDM Kesehatan di Bali. 2016.

20. Guspianto. Analisis Penyusunan Rencana Kebutuhan Sumberdaya Manusia (SDM) Kesehatan Puskesmas di Kabupaten Muaro Jambi. Pros Semin Nas Kesehat. Jur Kesehat Masy FKIK UNSOED 31 Maret 2012. 2012.

21. Notoatmodjo S. Pengembangan Sumber Daya Manusia. Jakarta: Rineka Cipta; 2009.

22. Annadoroh H IY. An Analysis on The Implementation of The Human Resources in The Health Field Planning Policy in Depok, 2017. J Indones Heal Policy Adm.2019;4(1):15.http//dx.doi.org/107454/ihpa.v4i12303. Tersedia pada : http//journal.fkm.ui.ac.id/ihpa/ Artic. 2019.

23. Tomblin Murphy, G.,Birch., MacKenzie,A. et al. A synthesis of recent analyses of human resources for health requirements and labour market dynamics in high-income OECD countries. Hum Resour Heal.2016;14(59):1-16. 
https://doi.org/10.1186/s12960-016-0155-2.

24. Sari F.,Hatta M. Analisis Perencanaan Kebutuhan Sumber Daya Manusia Kesehatan (Tenaga Analis) Berdasarkan Beban Kerja dengan Metode Workload Indicators of Staffing Need (WISN) di Puskesmas Keperawatan Sebeleat Putri Hijau Kabupaten Bengkulu Utara Tahun 2016. J Kesehat STIKES Prima Nusant Bukittingggi.2017;8(1):27-32. http://dx.doi. org/10.35730/jk.v8i1.279.g330.

25. Pagaiya N, Phanthunane P, Bamrung A, Noree T, Kongweerakul K. Forecasting imbalances of human resources for health in the Thailand health service system: application of a health demand method. Hum Resour Health. 2019;17(1):1-13. https://doi.org/10.1186/s12960-018-0336-2.

26. Mujiati, Yuniar Y. Ketersediaan Sumber Daya Manusia Kesehatan pada Fasilitas Kesehatan Tingkat Pertama dalam Era Jaminan Kesehatan Nasional di Delapan Kabupaten-Kota di Indonesia. Tersedia pada: http//ejournal. litbang.depkes.go.id/index.php/MPK/article/ download/4827/4644 201210. 2016;

27. Zurn P., Dal Poz, M.R., Stilwell, B.et al. Imbalance in the health workforce. BioMed Cent Hum Resour Heal. 2004;2(13):1-12. https:// doi.org/10.1186/1478-4491-2-13.Tersedia pada: http//www.human-resources-health.com/ content/2/I/I3. 2004; 